\title{
DOES SENSORY INTEGRATION AFFECT THE CLINICAL PICTURE OF AUTISM SPECTRUM DISORDER?
}

\author{
Neda Novakovic1, Milica Pejovic Milovancevic ${ }^{2}$ \\ ${ }^{1}$ Day Care Centre for Children and Adolescents with Development Disabilities, Belgrade, Serbia \\ 2University of Belgrade, Faculty of Medicine, Institute of Mental Health, Belgrade, Serbia
}

\section{KAKO SENZORNA INTEGRACIJA UTIČE NA KLINIČKU SLIKU POREMEĆAJA IZ SPEKTRA AUTIZMA?}

\author{
Neda Novakovićl, Milica Pejović Milovančević ${ }^{2}$ \\ ${ }^{1}$ Centar za smeštaj i dnevni boravak dece i omladine ometene u razvoju, Beograd \\ 2 Univerzitet u Beogradu, Medicinski fakultet, Institut za mentalno zdravlje, Beograd
}

\section{ABSTRACT}

Objective. The latest classification system of American Psychiatric Association (APA) DSM-5 includes sensory problems as one of the diagnostic criteria for autism spectrum disorder (ASD). The aim of this study was to determine the relationship between the severity degree of autism spectrum disorder and sensory integration by sensory domains.

Methods. The sample involved 40 participants with ASD, both sexes, aged 15-35. The study examined the relationship of ASD severity degree and sensory integration based on estimation of seven sensory modalities. Measures: The scale determining the degree of autistic disorder (Childhood Autism Raising Scale - CARS) completed by the therapists/special educators. The scale estimating sensory integration dysfunction (The Scale Estimating Sensory Integration Dysfunction in order to determine hyper - or hyposensitivity) completed by the parents and therapists/special educators.

Results. Except for the oral-gustatory sense, no correlation was found in this research between the severity degree of symptoms of ASD and sensory integration by sensory domains, according to the therapists' estimations. The absence of the correlation of sensory modalities and disorder severity were confirmed in other studies. The relationship across the sensory domains was found.

Conclusion. Sensory integration disorder is a general issue and is present in ASD population in all categories of disorder severity. It is important, as ASD population is heterogenous, to observe sensory domains separately in order to determine individual specificities in ASD population, and to administer all assessment categories in each sensory domain.

Key words: autism spectrum disorder; nervous system physiological phenomena; therapeutics

\section{INTRODUCTION}

Humans experience the world by seven senses: tactile (touch, pressure, pain, hot, cold), vestibular (movement, balance, sense of head position in rotating movements, space orientation), proprioceptive (gestures, muscle tonus, joints, recognition of a moving body part position relative

\section{SAŽETAK}

Cilj. Najnoviji klasifikacioni sistem Američke psihijatrijske asocijacije (APA) DSM-5 uključuje senzorne probleme kao jedan od dijagnostičkih kriterijuma poremećaja iz spektra autizma (PSA). Cilj studije bio je da se utvrdi veza između stepena težine poremećaja spektra autizma $i$ poremećaja senzorne integracije po čulnim domenima.

Metode. Uzorkom je obuhvaćeno 40 ispitanika sa PSA, oba pola, od 15 do 35 godina. Istraživanjem su ispitivani odnos stepena težine poremećaja iz spektra autizma $i$ poremećaja senzorne integracije na osnovu procena sedam čulnih modaliteta. Instrumenti procene su: skale za utvrđivanje stepena težine autističnog poremećaja (Chilhood Autism Rating Scale - CARS) na koju su odgovarali defektolozi, skale za procenu disfunkcije senzorne integracije (skala za procjenu disfunkcije senzoričke integracije za određivanje prekomjerne ili nedovoljne osetljivosti) na koju su odgovarali i roditelji i defektolozi.

Rezultati. U ovom istraživanju nije uspostavljena povezanost stepena težine simptoma poremećaja PSA $i$ poremećaja senzorne integracije po čulnim domenima, osim za oralno-gustativno čulo na osnovu procena defektologa. Ovaj izostanak povezanosti čulnih modaliteta $i$ težine poremećaja rezultat je i drugih istraživanja. Uspostavljena je veza između čulnih domena među sobom.

Zaključak. Poremećaj senzorne integracije je opšti $i$ prisutan je u populaciji PSA kod svih kategorija težine poremećaja. Usled heterogenosti populacije PSA posmatranje po čulnim domenima važno je za determinaciju individualnih specifičnosti kod populacije PSA, kao i da sve kategorije procene za svako čulo mogu biti zastupljene.

Kjučne reči: poremećaj autističnog spektra; fiziološki fenomeni nervnog sistema; terapija

to each other), auditory, visual, olfactory, oral-gustatory (1). In general, population the sensory integration processing is spontaneous. It includes information reception, transfer, processing and reaction, response (2). As the sensory integration processes start intrauterine (1, 3 ), early deficits on sensory processing level may determine further developmental pathways $(2,4)$. 
Sensory integration is established and developed in interaction with the environment (1). Sensory integration is basically an adaptive reaction which is the motor response to the stimulus from the environment. It is preceded by organized sensory stimuli, becoming more complex through interaction with the environment and thus affecting central nervous system organization (3). Sensory integration unites the principles of neurosciences, developmental psychology, special education and rehabilitation in order to explain the complex and important role of sensory perception and integration in development and functional behaviour (5).

The latest classification system of American Psychiatric Association (APA) DSM-5 includes sensory problems as one of the diagnostic criteria (6) for autism spectrum disorder. According to DSM-5, there are three categories of specific sensory processing: hyposensitivity, hypersensitivity and unusual sensory interests (1). Hyposensitivity is characterized by indifference to stronger stimuli or by extra stimulation seeking; hypersensitivity is characterized by environment stimuli avoidance, otherwise considered tolerable, usual for the general population, manifested by an unsuitable, inadequate response to the stimulus; sensory seeking is manifested by a strong carving for a certain sensory intake or its avoidance, often within the same sensory domain (6-8).

Sensory integration processing problems may be caused by deficits on the receptor level, or inadequate, insufficient or weak sensory integration within higher cortical structures (2). The problems of sensory integration are perceived through the lack of executive actions, poor motor planning, unsuitable movements, orientation problems in space and interaction with the environment. Harmonization of all single aspects of sensory processing has an impact on emotional experiences, attention thinking, learning $(3,9)$. Specific sensory processing has been identified since the first descriptions of ASD, but neurobiological bases of this specificity have not been determined yet.

Study objective was based on the fact that sensory symptoms may influence executive functions, planning, specific inappropriate behavioural responses in ASD, and, consequently the hypothesis was that sensory integration disorder is correlated with the severity of ASD. DSM-5 classification points to the presence of ASD severity (10). Although some research has examined this relationship, no consistent results have been provided regarding the correlation between the severity of ASD clinical picture and sensory processing disorder (11).

\section{SUBJECTS AND METHODS}

The sample involved 40 subjects of both sexes, aged 15-35 with ASD. All participants are the users of Day Care Centre for Children and Adolescents with Developmental
Disabilities in Belgrade. All were diagnosed with Pervasive Developmental Disorders according to ICD-10 diagnostic criteria. The diagnosis was confirmed by Autism Diagnostic Interview - Revised (ADI-R). All the participants had the intellectual disability as comorbid condition. The level of intellectual functioning was determined according to ICD-10, the data were collected from the participants' documentation. The research was based on a good clinical practice respecting all relevant ethical standards, keeping identity of each individual and taking care of personal data protection. Before conducting the research, the written consents were obtained from the caregivers as well as from the professionals working at Day Care Centre for Children and Adolescents with Developmental Disabilities, where these individuals have the rehabilitation therapeutical procedures.

The inclusion criteria were: the diagnosis of autism spectrum disorder, aged 15-35 of both sexes, the beneficiaries of the Day Care Centre for Children and Adolescents with Developmental Disabilities and written consents of parents/caregivers. The exclusion criteria were: the beneficiaries of the Day Care Centre for Children and Adolescents with Developmental Disabilities without Autism Spectrum Disorder, younger than 15 or older than 35, and unsigned parental/caregiver consents.

The research examined the relationship between the severity of autism spectrum disorder and sensory integration disorder by evaluating seven sensory modalities. The following instruments were used: The Scale determining the degree of autistic disorder (Childhood Autism Raising Scale - CARS), The scale estimating sensory integration dysfunction (The Scale Estimating Sensory Integration Dysfunction in order to determine hyper - or hyposensitivity). CARS scale was evaluated by therapists/special educators, while The Scale Estimating Sensory Integration Dysfunction was evaluated by therapists and parents together. The total CARS score was compared to sensory domains, assessed by parents and therapists separately and the mutual relationship of sensory domains was examined, too.

\section{Measurement Instruments}

1. The Scale for determining the degree of autistic disorder (Childhood Autism Raising Scale - CARS) (12), used for identifying individuals with autism and determining severity of autism symptoms, the assessment made by direct observation. It is used for the individuals older than 2. The scale is composed of 15 items completed by a therapist. The content areas assessed are: social, emotional communication skills, repetitive behaviours, game organization and everyday activities (routines) and unusual sensory interests. The total CARS score determines three categories: severe autism (scores from 37 to 60 ), a mild to moderate (scores 31 to 36 ) and nonautistic range (scores 15 to 30 ). 
2. The Scale Estimating Sensory Integration Dysfunction (14). The Scale estimates sensory integration disorder by examining seven sensory domains: tactile, vestibular, proprioceptive, visual, auditory, olfactory, oralgustatory. The Scale evaluates three categories by sensory domains: hyposensitivity, normal sensitivity, hypersensitivity.

The data were processed by methods of descriptive statistics and the method determining correlation of numerical variables. Descriptive statistics included mean values, median, standard deviation. Numerical variable correlation was determined by Pearson coefficient of correlation. All data were processed in the appropriate statistical programme - SPSS.

\section{RESULTS}

The sample consisted of 40 participants, 11 females and 29 males. The average age was $23.7 \pm 4.15$, the youngest being 16, and the oldest being 35 . Five participants were in the category of moderate severity and all other in the category of severe ASD. The majority of participants functioning as severe intellectual disability (n $=20), 2$ as a mild intellectual disability, and 9 as moderate and 9 as profound intellectual disability. The results have shown that the severity of the disorder according to CARS is higher on lower levels of intellectual functioning as presented in Table 1.

Table 1. Sample description regarding the severity of ASD based on CARS and the level of intellectual functioning according to ICD-10

\begin{tabular}{|c|c|c|c|c|}
\hline $\begin{array}{c}\text { Level of intellectual } \\
\text { functioning by ICD-10 }\end{array}$ & \multicolumn{4}{|c|}{ Severity degree of the disorder by CARS } \\
\hline & N & Mean \pm SD & Min & Max \\
\hline F 70 & 2 & $36.00 \pm 0.00$ & 36.00 & 36.00 \\
\hline F 71 & 9 & $44.72 \pm 4.13$ & 40.00 & 51.00 \\
\hline F 72 & 20 & $45.43 \pm 5.42$ & 36.50 & 56.00 \\
\hline F 73 & 9 & $48.00 \pm 5.78$ & 37.00 & 54.50 \\
\hline Total & 40 & $45.38 \pm 5.55$ & 36.00 & 56.00 \\
\hline
\end{tabular}

The level of intellectual functioning by ICD-10: F-70 - Mild intellectual disability, F71 -

Moderate intellectual disability, F72 - Severe intellectual disability, F73 - Profound intellectual disability

\section{ASSESSMENT ACCROSS SENSORY DOMAINS BY SPECIAL EDUCATORS}

45

PROPRIOCEPTIVE

40

35

30 TACTILE VESTIBULAR

$\mathbf{2 2}$
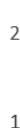

10

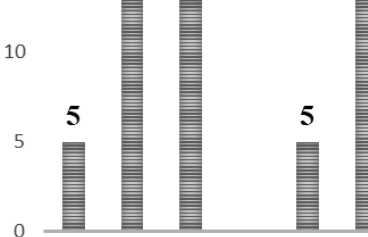

0

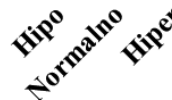

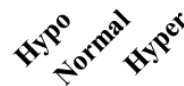

19

Figure 1. Sensory integration estimation by sensory dom
OLFACTORY

VISUAL

40

ORAL-GUSTATORY

25

AUDITORY

34

6

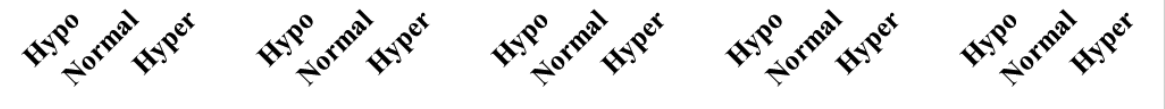


Table 2. Correlation between severity of ASD by CARS and sensory integration by sensory domains, and sensory domains among themselves according to the therapists' assessments.

\begin{tabular}{|l|c|c|c|c|c|c|c|}
\hline CARS score & Tactile & Vesibular & Propriocept. & Auditory & Visual & Olfactory & Oral.-gust. \\
\hline CARS score & -.085 & -.143 & -.008 & -.129 & .164 & -.145 & $-.317^{*}$ \\
\hline Tactile & & $.423^{* *}$ & .014 & $.350^{*}$ & .117 & -.021 & -.040 \\
\hline Vestibular & & & .205 & .090 & .070 & .061 & .106 \\
\hline Proprioceptive & & & & .018 & -.054 & .138 & .086 \\
\hline Auditory & & & & & .188 & -.065 & -.100 \\
\hline Visual & & & & & & -.107 & .063 \\
\hline Olfactory & & & & & & & .130 \\
\hline Oral-gustatory & & & & & & & \\
\hline
\end{tabular}

**Correlation is significant when $\mathrm{p} \leq 0.01$ two-way comparison *. Correlation is important when $\mathrm{p}<0.05$, CARS score - severity of ASD

Table 3. Correlation of ASD severity by CARS and sensory integration by sensory domains and sensory domains among themselves according to the parent reports.

\begin{tabular}{|l|c|c|c|c|c|c|c|}
\hline CARS score & Tactile & Vesibular & Propriocep. & Auditory & Visual & Olfactory & Oral.-gust. \\
\hline CARS score & .103 & .119 & -.052 & -.021 & .196 & -.063 & -.271 \\
\hline Tactile & & .029 & -.131 & .292 & $.357^{*}$ & -.150 & -.039 \\
\hline Vestibular & & & .127 & $.364^{*}$ & $.318^{*}$ & -.061 & .016 \\
\hline Proprioceptive & & & & -.149 & -.104 & .130 & -.005 \\
\hline Auditory & & & & & $.395^{*}$ & -.164 & .065 \\
\hline Visual & & & & & & -.175 & -.053 \\
\hline Olfactory & & & & & & & $.502^{* *}$ \\
\hline Oral-gustatory & & & & & & & \\
\hline
\end{tabular}

**.Correlation is significant when $\mathrm{p} \leq 0.01$ two-way comparison *.Correlation is significant when $\mathrm{p}<0.05$, CARS score - severity of ASD

\section{ASSESSMENT ACCROSS SENSORY DOMAINS BY PARENTS}

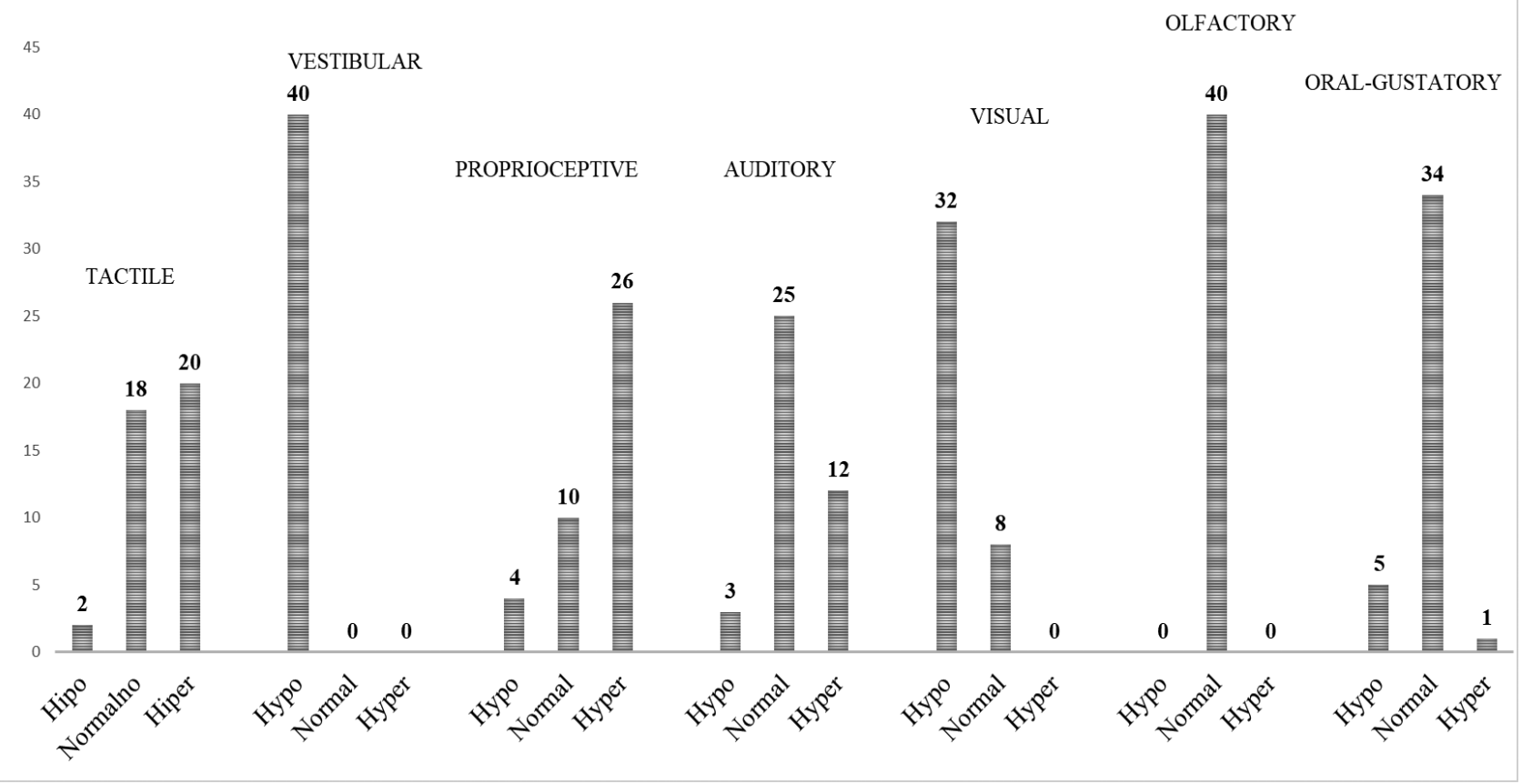

Figure 2. Sensory integration evaluation by sensory domains in ASD according to the parental rating. 
Hyposensitivity and hypersensitivity were present in sensory processing in all sensory domains, except for olfactory sense in all participants. All 40 participants were in normal sensory processing range, as shown in Figure 1.

According to the parental evaluations hyposensitivity or hypersensitivity were present in all sensory domains, except for olfactory sense which agrees with the therapists' evaluations. All 40 participants were in normal sensory processing range of olfactory sense (Figure 2).

There is no statistically significant correlation between the ASD severity and sensory processing by sensory domains, except for the oral-gustatory sense where the negative correlation was found (Table 2). There is a positive correlation of the vestibular sensory domain and tactile sensory domain and the auditory sensory and tactile domain.

Regarding the correlation between severity of ASD and sensory integration disorder by sensory domains on CARS and the Scale estimating the dysfunction of sensory integration the results obtained are shown in Table 3 . Examining the correlation across sensory domains themselves based on the parent reports, as presented in Table 3. According to the parental evaluations, there is no statistically significant correlation between the severity of the disorder and sensory processing by sensory domains. A positive correlation was found between vestibular and visual sensory domains as well as between vestibular and auditory sensory domains.

\section{DISCUSSION}

The main objective of the present study was to determine the relationship between severity of ASD and sensory integration disorder through assessing sensory domains. Tactile processing was found to be mostly normal to hypersensitive, while other studies have indicated the existence of high fluidity and tactile assessment variability depending on the situation and stimuli $(15,16)$. The vestibular sense was rated in all three categories (hyposensitivity, hypersensitivity and unusual sensory interests) by the therapist, whereas it was hyposensitivity by the parental reports. The specificity of the vestibular system sensory processing is considered to be potentially the central problem of sensory integration in ASD and deeper understanding of it may help comprehend the specificities of behaviour in ASD population (17).

Proprioception was also estimated differently by the therapists and parents, that is, all three categories were included in the therapists' reports, while hyposensitivity proprioception was dominant in parental reports. The studies have demonstrated that the problems on proprioception level in ASD population can affect the shortages in praxis organization, motor planning, body posture control influencing negative forms of behaviour, making it impossible to engage in everyday activities (18).
The olfactory sense was evaluated in the category of normal processing for all participants by therapists and parents as well. There are few studies examining the sense of smell in ASD, but some indicate the similar results, that is, no specificities are present in sensory processing, and $5 \%$ of ASD population belong to hypo- or hypersensitive categories $(19,20)$.

In the sensory integration problems, the most prominent characteristics in processing are shown in visual perception, especially hyposensitivity. This was determined in other studies as well (21), connecting visual hyposensitivity with the ability of the perception of details (22). The auditory sense was evaluated in all three categories. As reported in the literature auditory processing in ASD is the problem of discrimination, separation of simultaneously incoming sounds (23), especially emphasizing the disability of detection and discrimination of voices and speech (24).

The oral-gustatory sense was evaluated in all three categories, but the therapist and parent assessments of this sensory modality were different. Fewer number of studies exploring this domain indicate the problems of stereotypic and unvarying diet $(25,26)$, relating it to the repetitive / stereotyped behaviour, as well as the increased body mass index (Body Mass Index- BMI) $(4,26)$.

By examining the correlation between the severity of ASD based on CARS scale and sensory integration disorder across sensory domains, the only relationship found was between the oral-gustatory sense and the severity of ASD by the therapists' assessments. This negative correlation means that the higher gustatory hyposensitivity is, the higher disorder severity. No other relations between sensory domains and the disorder severity were identified.

Other research has not discovered the relationship of ASD severity and the problems of sensory processing across the senses either $(17,27,28)$. The absence of the relationship which can be explained by the fact that sensory integration disorder is present in ASD population in all ages and degrees of severity (29). Furthermore, some studies indicate that there is no correlation with ASD severity and sensory integration disorder in adolescents and adults with ASD (17). The possible explanation could be that individuals with higher level of intelligence develop better strategies over time, helping them overcome sensory integration disorder $(6,17)$.

The interpretation of the oral-gustatory sense relation with the severity of the disorder suggests that oralgustatory hyposensitivity is present with a higher degree of severity, which is related to the oral stimulation needs, frequent food overconsumption, stereotypic diet $(4,26)$. In addition, the specificity of the oral-gustatory sense is that it includes tactile, proprioceptive and olfactory sensations (temperature and food structure detection, chewing, 
swallowing), suggesting a complex mutual relationship of the senses which is manifested by selecting and searching for certain food items (26). The severity of the disorder is additionally related to the oral-gustatory sense as the individuals with severe forms of ASD, accompanied by intellectual disability, focus the majority of their activities on nutrition. They perform stereotyped / repetitive behaviours through food consumption, which is mostly reflected in daily organisation.

The positive and strong correlation was established between the vestibular sensory domain and the tactile sensory domain, as well as between the auditory and tactile sensory domains by the therapists' evaluations. According to the parental reports the positive correlation was found between the visual and tactile sensory domains, as well as the auditory and vestibular domains. This indicates that sensory domains correlate mutually no matter the evaluation category. The mutual correlation of sensory domains indicates the general disorder of sensory integration, namely the observation by sensory domains provides important information about individual specificities of ASD (4). Additionally, the specific sensory processing on the level of one sense is sufficient to affect the general sensory integration disorder $(4,14,17)$.

Some studies suggest that sensory processing categories are very heterogenous in ASD population (30). The results of normal processing may be obtained in each sensory domain, while the specific sensory processing appears with complex simultaneous stimuli (4). The research examining the assessment of sensory modalities are not uniform, which highlights sensory processing complexity in ASD (22). In order to get to know all the variations of sensory processing data in ASD and individual specificities in ASD, it is important to conduct examination by sensory domains.

Study implications could be also considered here. Besides observing the sensory integration disorder as a general one, it is important to perceive all specificities in each sensory modality for deeper understanding of sensory challenges in population with severe autism spectrum disorder. In practice, the assessment of sensory integration by sensory modalities may be of greater importance for setting individual objectives and making plans of the treatment, as well as developing adequate strategies in everyday activities.

In conclusion, this study has not found the relationship between severity of ASD and sensory integration disorder by sensory domains except for the oral-gustatory sense according to the therapists' evaluations. The absence of correlation between sensory modalities and disorder severity has also been found in other research, and the explanation is that sensory integration disorder is general and present in ASD population of all disorder severity categories. It is also important to take into account that observation by sensory domains is significant for identifying individual specificities in ASD population due to heterogeneity of the population, and that all categories can be present in each sensory domain. The mutual relationship across sensory domains was established, indicating the relationship and integrative processes of sensory processing, as well as that the processing disorder on the level of one sense is sufficient to cause sensory integration problems, which confirms the complexity of sensory processing.

\section{REFERENCES}

1. Ayers AJ, Robbins J. Sensory integration and the child. Los Angeles: Western Psychologocal Services, 1998.

2. Claeys KG, Orban GA, Dupont P, Sunaert S, Hecke $\mathrm{PV}$, Schutter ED. Involvement of multiple functionally distinct cerebellar regions in visual discrimination: a human functional imaging study. Neuroimage 2003; 20: 840-54.

3. Ayres AJ, Robbins J. Sensory integration and the child: understanding hidden sensory challenges. Los Angeles: Western Psychological Services, 2005.

4. Thye MD, Bednarz HM, Herringshaw AJ, Sartin EB, Kana RK. The impact of atypical sensory processing on social impairments in autism spectrum disorder Melissa. Dev Cogn Neurosci 2018; 29: 151-67.

5. Devlin S, Healy O, Leader G, Hughes BM. Comparison of behavioral intervention and sensoryintegration therapy in the treatment of challenging behavior. J Autism Dev Disord 2011; 41: 1303-20.

6. American Psychiatric Association. Diagnostic and statistical manual of mental disorders: DSM-5. Washington, D.C: American Psychiatric Association, 2013.

7. Tavassolia T, Miller LJ, Schoen SA, Broute JJ, Sullivanf J, Baron-Coheng S. Sensory reactivity, empathizing and systemizing in autism spectrum conditions and sensory processing disorder. Dev Cogn Neurosci 2018; 29: 72-7.

8. Hazen EP, Stornelli JL, O'Rourke JA, Koesterer K, McDougle CJ. Sensory symptoms in autism spectrum disorders. Harv Rev Psychiatry 2014; 22: 112-24.

9. Mamić D, Fulgosi-Masnjak R. Editors. Senzorna integracija kao ključ za razumijevanje ponašanja djece s teškoćama u razvoju - model primjene i vrednovanja. Zbornik radova sa 9. Kongresa s međunarodnim sudjelovanjem „Kvaliteta i standardi usluga edukacijskih rehabilitatora". Varaždin: Savez defektologa Hrvatske, 2012.

10. Weitlauf AS, Gotham KO, Vehorn AC, Warren ZE. Brief Report: DSM-5 “Levels of Support:” a comment on discrepant conceptualizations of severity in ASD. J Autism Dev Disord 2014; 44: 471-6. 
11. Kern JK, Trivedi MH, Grannemann BD, et al. Sensory correlations in autism. Autism 2007; 11: 123-34.

12. Schopler E, Van Bourgondien ME, Wellman GJ, Love SR. The childhood autism rating scale. $2^{\text {nd }}$ ed. Los Angeles: Western Psychological Services, 2010.

13. Fulgosi-Mašnjak R, Osmačević L, Lang M; Viola SG (prevod i adaptacija). Sustav za procjenu disfunkcije senzoričke integracije. Priručnik 2002. Zagreb: Sveučilište u Zagrebu, Edukacijsko-Rehabilitacijski fakultet, 2004.

14. Gal E, Dyck MJ, Passmore A. Relationships between stereotyped movements and sensory processing disorders in children with and without developmental or sensory disorders. Am J Occup Ther 2010; 64: 45361.

15. Brown NB, Dunn W, Relationship between context and sensory processing in children with autism. Am J Occup Ther 2010; 64: 474-83.

16. Lane AE, Dennis SJ, Geraghty ME. Brief report: further evidence of sensory subtypes in autism. J Autism Dev Disord 2011; 41: 826-31.

17. Kern JK, Garver CR, Grannemann BD, et al. Response to vestibular sensory events in autism. Res Autism Spect Disord 2007; 1: 67-74.

18. Blanche EI, Reinoso G, Chang MC, Bodison S Proprioceptive processing difficulties among children with autism spectrum disorders and developmental disabilities. Am J Occup Ther 2012; 66: 621- 4.

19. Dudova I, Vodicka J, Havlovicova M, Sedlacek Z, Urbanek T, Hrdlicka M. Odor detection threshold, but not odor identification, is impaired in children with autism. Eur Child Adol Psychiatry 2011; 20: 333-40.

20. Robertson AE, Simmons DR. The sensory experiences of adults with autism spectrum disorder: a qualitative analysis. Perception 2015; 44: 569-86.

21. Simmons DR, Robertson AE, McKay LS, Toal E, McAleer P, Pollick FE. Vision in autism spectrum disorders. Vision Res 2009; 49: 2705-39.
22. Dakin S, Frith U. Vagaries of visual perception in autism. Neuron 2005; 48 : 497-507.

23. Lepisto T, Kuitunen A, Sussman E, et al. Auditory stream segregation in children with Asperger syndrome. Biol Psychol 2009; 82: 301-7.

24. Curtin S, Vouloumanos A. Speech preference is associated with autistic-like behavior in 18-monthsolds at risk for Autism Spectrum Disorder. J Autism Dev Disord 2013; 43: 2114-20.

25. Wiggins L, Robins D, Bakeman R, Adamson L, Brief report: sensory abnormalities as distinguishing symptoms of autism spectrum disorders in young children. J Autism Dev Disord 2009; 39: 1087-91.

26. Chistol LT, Bandini LG, Must A, Phillips S, Cermak SA., Curtin C. Sensory Sensitivity and Food Selectivity in children with Autism Spectrum Disorder. J Autism Dev Disord 2018; 48: 583-91.

27. Đorđevic M, Glumbić N, Langher V. Neki aspekti senzorne disfunkcije kod mladih osoba sa poremećajem iz spektra autizma. Specijalna edukacija i rehabilitacija 2019; 18: 43-61.

28. Crane L, Goddard L, Pring L. Sensory processing in adults with autism spectrum disorders. Autism 2009; 13: 215-28.

29. Leekam SR, Nieto C, Libby SJ, Wing L, Gould J. Describing the sensory abnormalities of children and adults with autism. J Autism Dev Disord 2007; 37: 894-910.

30. DeBoth KK, Reynolds S. A systematic review of sensory-based autism subtypes. Res Autism Spectr Disord 2017; 36: 44-56.

31. Tavassoli1 T, Miller LJ, Schoen SA, Nielsen DM, Baron-Cohen S. Sensory over-responsivity in adults with autism spectrum conditions. Autism 2014; 18: 428-32. 